dziecięcych akcentując duchową matczyność (geistige Müterlichheit) oraz rozwój instytucji edukacyjnych dla dzieci i ewolucję roli kobiety.

W części II omówiono instytucjonalne i normatywne regulacje i praktyki w zakresie edukacji dziewcząt w latach $1870-1933$ oraz tzw. dhuga drogę do matury (Der lange Weg zum Abitur).

Socjalizacja dziewcząt głównie poprzez koedukację oraz ich działalność w ruchu hitlerowskim: Bund Deutscher Mädel - stanowi przedmiot części III.

W części IV Autorki i Autorzy rekonstruują drogę kobiet od wykształcenia średniego do nauki, czyli możliwości studiowania (Von der Bildung zur Wissenschaft) w latach 1870-1945. Dowiadujemy się m.in. o rozwoju naukowym Edyty Stein oraz o tym, ze pierwszą kobieta profesorem pedagogiki była w Niemczech Mathilda Vaerting (1884-1977).

Możliwość kształcenia kobiet w różnych dziedzinach i zawodach w latach 1948-1990 ukazano w części piątej, zaś stopniowe zwiększanie dostępu do studiów wyższych w latach 1849 - 1990 - w części szóstej.

Interesujące są porównania dotyczące polityki NRD $w$ sprawie edukacji kobiet i badań nad tym zagadnieniem jako komponentu walki politycznej o pełną realizację założeń marksizmu.

Książka jest bogato udokumentowana źródlami oraz literaturą przedmiotu. Posiada wykaz osób, indeks rzeczowy oraz informacje o autorach.

Jan Hellwig

\title{
Johann Amos Comenius. Allverbesserung (Panorthosia), Eingelei- tet, übersetzt und erläutert von Franz Hofmann, Frankfurt a/Main, Berlin, Bern, New York, Paris, Wien 1998, ss. 429
}

Dzięki pracom znanego w międzynarodowym świecie nauki komeniologa, emerytowanego obecnie profesora, wieloletniego kierownika Zakładu Historii Pedagogiki na Uniwersytecie Marcina Lutra w Halle Franza Hofmanna (ur. 1922) ukazała się przetłumaczona przez niego $\mathrm{z}$ łaciny na język niemiecki 6-ta część pracy J.A. Komeńskiego $O$ naprawie spraw ludzkich. Część ta nosi tytuł Panorthosia. Przedstawia w niej
Komeński strukturę porządku światowego, instytucje służące człowiekowi, ich cele i zadania.

Jest to pierwsze thumaczenie tej pracy w całości na język niemiecki.

Książka ukazała się w cyklu Erziehungskonzeptionen und Praxis, Bd. 37, a wydawca jest Gerd-Bodo Reinert.

Jan Hellwig

\section{Vitae Scholasticae. The Yournal of Educational Biography, Tom 17, 1998, nr 2}

W amerykańskich (ale nie tylko) pracach historyczno-pedagogicznych ważne miejsce zajmują prace biograficzne. Rekonstrukcje biograficzne traktowane są jako ważny komponent odtwarzania procesu dziejowego, studiów historyczno-edukacyjnych i wpływu jednostek znaczących na rozwój dziejów.
Istnieją międzynarodowe stowarzyszenia biografii edukacyjnych (np. International Society for Educational Biography), czy też instytuty naukowo-badawcze w tej dziedzinie (np. American Biographical Institute).

Organem Międzynarodowego Stowarzyszenia Biografii Edukacyjnej jest półrocznik 
Vitae Scholasticae ukazujący się w językach angielskim, hiszpańskim, francuskim lub niemieckim przy Nothern Illinois University, a wydawcą jest Lucy Towsend (Caddo Gap Press, 3145 Geary Boulevard, Snite 275, San Francisco, California 94118 USA). Zamieszcza się $w$ nim prace poświęcone teorii biografii edukacyjnej, wspomnieniom, przeżyciom, biografie pedagogiczne. Prezentuje także inne pisma naukowe i wykazy nowych ksiazżek.

Jan Hellwig

\section{Jędrzej Sobczak, „Nowe wychowanie” w polskiej pedagogice okresu Drugiej Rzeczypospolitej (1918-1939), Wydawnictwo Uczelniane WSP w Bydgoszczy, Bydgoszcz 1998, ss. 446}

Książka ta, na pojawienie się której na rynku wydawniczym od dawna czekano, jest drugim, zmienionym wydaniem pracy Jędrzeja Sobczaka, która jako dwuczęściowa monografia ukazała się pod tytułem Recepcja idei „nowego wychowania" w polskiej pedagogice okresu miedzy wojnami (Bydgoszcz 1978-79). Autor ukazuje w niej przemiany, jakim w okresie Drugiej Rzeczypospolitej ulegała teoria i praktyka wychowawcza pod wpływem rozwijającego się od początku XX wieku w krajach Europy i Stanach Zjednoczonych ,ruchu nowego wychowania”. Dynamikę tych przemian przedstawiono poprzez przytoczenie teoretycznych rozważań i podanie praktycznych przykładów rozwiązań wychowawczych podejmowanych w tym czasie w Polsce.

Na podstawę do prezentowanych w pracy ustaleń złożyła się uważna lektura niezmierzonej ilości książek, broszur oraz artykułów z zakresu ówczesnego piśmiennictwa pedagogicznego. Zamierzeniem autora jest również przybliżenie wspólczesnemu czytelnikowi, na łamach swej książki, wielu interesujących pozycji pedagogicznych, wydanych wówczas, a stosunkowo słabo dzisiaj znanych.

Krzysztof Jakubiak

\section{Bibliografia historii wychowania (druki zwarte wydane w Polsce w L. 1997-1998)}

Andrzejak A., Nawrocka M., Wąsikowska-Trawińska A, Śladami Dokty. Wanda Bleńska - nadanie imienia Piqtkowskiej Szkole Uspolecznionej w Poznaniu, Poznań 1997, ss. 77;

Ars Edukandi, T. 1, Gdańsk 1998, ss. 248;

Bachta E., Mlodzieżowe konspiracyjne organizacje niepodlegościowe $w$ województwie rzeszowskim w latach 1944 - 1956, Przemyśl 1997, ss. 231;

Banach A.K, Mlodzież chlopska na Uniwersytecie Jagielloniskim w latach 1860/61 -1917/18, Kraków 1997, ss. 359;
Bartnicka K., Wychowanie patriotyczne w szkolach Komisji Edukacji Narodowej, Warszawa 1998, ss. 247;

Baszkiewicz J, Mlodość uniwersytetów, Warszawa 1997, ss. 197;

Bereźnicki F., Hasla "nowej szkoly" w dydaktyce Drugiej Rzeczypospolitej, Toruń 1998; ss. 213 ;

Bieńkowski T., Jan Amos Komeński o nauczaniu i wychowaniu, Pułtusk 1998, ss. 95; 